\title{
The Cross as a Source of Knowledge and the Language of the Heart
}

The heart has its reasons, which reason does not know.

BLAISE PASCAL

It is only with the heart that one can see rightly;

what is essential is invisible to the eye.

ANTOINE DE SAINT-ÉXUPERY

We have already defined the main purposes of Newman's quest - to analyse how man thinks under concrete circumstances and how he assents to propositions (notional assent) or to reality (real assent), and, ultimately, whether he can arrive at certitude in the concrete. In Chapter 2 I sought to characterise Newman's theory of knowledge in the concrete, i.e. how we come to assent in our daily experience and whether we can accomplish certitude. His principal position was that of "metaphysics in the singular," in which selfhood rises to the point of being the main cognitive centre. Therefore, Newman uses such terms as personal result, cogitative method. This centre is, at the same time, very unsteady and unreliable, for it is the living centre of the human being that undergoes all the contingencies of the living entity, but at the same time the only one we have immediate access to. We have to use ourselves, however, all these shortcomings-hesitations, prejudices, uncertainties, weaknesses-notwithstanding.

In one of his sermons, Newman characterises our existential situation. He writes that people willingly follow their inclinations, "they are guided by pleasure and pain, not by reason, principle, or conscience; and they do not attempt to interpret this world, to determine what it means, or to reduce what they see and feel to system. But when persons, either from thoughtfulness of mind, or from intellectual activity, begin to contemplate the visible state of things into 
which they are born, then forthwith they find it a maze and a perplexity. It is a riddle which they cannot solve. It seems full of contradictions and without a drift. Why it is, and what it is to issue in, and how it is what it is, and how we come to be introduced into it, and what is our destiny, are all mysteries."1 Thus, we can see that the author of these words is well aware of at least two distinct states of our existence: the theoretical one in which we are engaged in intellectual activity and can assume a safe distance towards the vibrant current of events, and the actual one when we commonly decide about matters that personally concern us. In this sense, Newman's message goes counter to the universalizing tendencies of the Enlightenment, especially the secular trends of the epoch of reason and experience. John Henry sought to restore the person and his idiosyncratic thinking to their right position. His method did not concentrate on coming up with some overall theory, but rather on accompanying the human being in his concrete struggle with daily reality. At the same time, such a being is called upon to respond to duties that go beyond what is experiential and reach the supernatural. Such a being, spread between the here and now and the metaphysical beyond, must find personal resources to brave this predicament. In my interpretation of Newman I have constantly made recourse to Edith Stein, especially at the moments of their mutual inspiration.

In order to render the special position of the person, his tension between the truth and personal assent to it, Newman attempts first a thorough study of the theory of knowledge, bearing in mind all the time the specific human condition. He is therefore aware that the original "functional disarrangement" - as we called it after him in Chapter 2-is a very unwelcome situation, but, at the same time, something that we have to take into account, if we aspire to portray a realistic picture of the human being. Doomed to his contingent fortune, the person must come to grips with his individual (internal and external) circumstances, for-weak as he is-he is endowed with respective faculties to accomplish that which he is called to accomplish. He is endowed with reason, conscience, and the capability of abiding by principles. He is like a tree bending under the strong gusts of wind, firmly holding the ground with its roots. Reason, as the natural personal faculty, must be understood in its proper context. It is true that Newman in the quote above emphasizes the role of reason in overcoming chaos, but reason must be accepted as it is in the person himself. We should rely on it, but not place too much confidence in it, we should mind its limitations. Let us note that, in the quote above, reason is placed side by side with conscience.

1 J. H. Newman, Parochial and Plain Sermons, 1229. 
Newman explains his understanding of reason in the Apologia. He agrees with the stance of classical philosophy that the primary object of reason is to attain truth. At the same time, he is aware that it is right reason that is meant here. Therefore, he explains his position: "I have no intention at all of denying, that truth is the real object of our reason, and that, if it does not attain to truth, either the premiss or the process is in fault; but I am not speaking here of right reason, but of reason as it acts in fact and concretely in fallen man [...]; I am considering the faculty of reason actually and historically; and in this point of view, I do not think I am wrong in saying that its tendency is towards a simple unbelief in matters of religion."2 Newman is constantly asking about reason in a concrete human being surrounded by his changing circumstances. That is why, the Cardinal proposes a more apt instrument to cope with them.

The reference to "pleasure and pain" in the quote above obviously makes us think of nineteenth-century utilitarianism. For Jeremy Bentham (1748-1832), pleasure and pain were the two masters which guided human nature. Thus, man was reduced to two reactions placed at two extremes: either to seek pleasure or to avoid pain. The abandonment of this simplistic philosophy would mean creating a system, i.e. turning all our sense data into a coherent whole, seeking a more profound interpretation of what we can experience. We need to approach the surrounding world not only with what we transitorily feel as enticing, what is pressing on us at the moment, what is expedient, but constantly attempt to create one overall sense from that which appeals to us. For that, theoretical comprehension is insufficient, as I have been trying to prove; we need to gain personal command of the sense data at hand. Let me remind the reader how challenging this task is. We have to confront the abyss of existence in which only some elements are explicit, others being implicit, i.e. unnamed. Indeed, this personal command we wish to gain calls for a more sensitive and adequate instrument than a general knowledge of physical processes. We can find the source of this knowledge inside us. This path insidewhich will be dealt with at greater length in Chapter 4-will warrant, on the one hand, an authentic pledge of individuality and, on the other, a steady core of personality. For Newman and Stein, the soul is the core, the heart is the measure, and the cross is the ultimate point of reference. And these are the areas in which the two thinkers are particularly integrated. And the heart is guided by what Newman called "higher logic."

Let us note that the logic of the heart was propounded in the nineteenth century as an opposition to the equalizing transcendental tendencies, i.e.

2 J. H. Newman, Apologia, 163. 
constructivism feels at home in the divorce from reality, when man apparently free from all obstacles can create his world anew. Surprisingly, if he wishes to plan everything, the plans turn into their opposite. The so-called ideal political systems then become systems of the worst oppression. And why should we wonder? Reality translated into concepts is no longer reality, when words are only words-conventional markers-starved of their real and nutrient contents. The illusion is that only the explicit level exists, and the implicit depth is neglected. It is true that the explicit constitutes only a part, and not a very large part, of the person. To grasp the implicit area, we need a more adequate instrument.

\section{1 \\ Going Inside-Meeting God}

The soul is the life-giving form of the body. It is at home in its innermost region. When the soul ascends to God, it reaches out to something outside, but, at the same time, goes inside. God is a mystery which "attracts us constantly." This mystery reveals itself to us, but never completely. A created spirit can ascend to God-we read in Edith Stein —only by transcending itself and sinking "by this very fact into a secure position of rest." ${ }^{3}$ This sinking into "a secure position of rest" reminds us of Newman's understanding of certitude, for being at tranquil rest is the main characteristic of certitude. Let us remember, however, this most intriguing (indeed, there is something powerfully beautiful in it) hesitation between certitude and simple assent, i.e. the person's immediate response to value; Newman, as we remember, was inclined to emphasize simple assent. Since St John of the Cross "calls God the deepest centre or point of rest of the soul," the striving after certitude is striving after God, but above all striving after the self is such. Indeed, if we have the right to understand Newman's certitude as finding one's true self, in like manner we can surmise that, in his view, this discovery must be identical with finding God. How else can it be, if reposing in certitude is coequal to one's principal task?

According to Newman, the doctrine of the Cross is "the true interpretation of this world," a statement which is in accordance with his claim that the Cross is the measure of the world. And the Cross is the fulcrum for the abyss of existence to find its orientation in the world. The message of the Cross is not theoretical knowledge, therefore it is "not on the surface of the world [...]; it is

3 E. Stein, The Science of the Cross: A Study of St. John of the Cross, trans. by H. Graef, London: Burns \& Oates, 1960, 115 . 
a hidden doctrine; it lies under a veil [...]." I gather that the conclusion from these words is all too obvious - the doctrine of the Cross must be accepted by the person and realized. As Newman explains, "when received into the faithful heart, there it abides as a living principle, but deep, and hidden from observation." 4 This remark is an excellent corroboration of our former analysis. I think we may, for instance, identify the Cross and the kind of knowledge it conveys with the implicit part of our cognition; after all, its knowledge is deep and hidden from observation. Let us note the inherent cohesion of Newman's thinking and how he comes forward to meet his German Carmelite translator. I am always fascinated by the way the initially muddled paths ultimately converge and form a wider current. They seem to have found this sensitive and adequate instrument in the doctrine of the Cross and the heart.

Our experience would testify to the contrary, for it seems that sufferingwhich is symbolised by the Cross-is ubiquitous, that, in fact, there are more sorrowful than joyful moments. Therefore, the true doctrine of the Cross, as depicted in the aforementioned quotes, must denote something else, something much more profound than the visible aspect of suffering, "for truth is not on the surface of things, but in the depths." The author of these words then goes on to appeal to "the language of figure, the heart of religion." In other words, the essence of religion is as hidden as personal experience, or, rather, the person's individual response to experience. The message of the Cross and the heart seems to converge and express something essentially profound - the core of Christian religion. Let me remind the reader what Edith Stein wrote about the Cross to Mother Prioress, namely, that one can learn it by living it. This is something analogous to Newman's realization or his simple real assent. Is that not the essence of religion - to move forward in confidence and faithfulness to God?

By way of analogy, Newman explains that "the heart may be considered as the seat of life; it is the principle of motion, heat, and activity; from it the blood goes to and fro to the extreme parts of the body. It sustains the man in his powers and faculties; it enables the brain to think; and when it is touched, man dies." ${ }^{\prime \prime}$ As the physical heart sets the whole of the body in motion and makes the blood circulate, "the sacred doctrine of Christ's Atoning Sacrifice is the vital principle on which the Christian lives, and without which Christianity is not."7 In his Parochial and Plain Sermons, Newman is writing about "spiritual

\footnotetext{
4 J. H. Newman, Parochial and Plain Sermons, 1232.

5 Ibid., 1232.

6 Ibid., 1233 .

7 Ibid., 1233 .
} 
knowledge," that is, faith, which "carries with it its own evidence, and admits of no mistaking the true spiritual conviction being unlike all others." 8

Just as inanimate matter is drawn to the centre of the earth by the power of gravity, so too the spiritual beings are drawn to God. A material object retains its gravitational (centripetal) motion as long as it is at a distance from the centre. In like manner, the spiritual being is under the power of attraction so long as it is far away from God. Stein uses the term "ladder," the same word used by Newman, we remember, in his analysis of real words. The Jewish author notes: "The soul ascends to God, that is, to union with him, by the steps of a ladder. The higher it ascends to him, the deeper it descends into itself: the union takes place in the innermost sphere of the soul, in its deepest ground. If this seems contradictory it should be remembered that these are only different spatial images supplementing each other and intended to indicate something utterly remote from space, which cannot be adequately represented by anything taken from the realm of natural experience." ${ }^{\prime 9}$ This parallel between going to God and going inside oneself is most amazing here. For it means that going to God is not equal to losing oneself. On the contrary, by approaching God the human being approaches his true self. Such is the message from Newman and Stein. And this message is in accordance with St Augustine and his mystical teaching.

But unlike the physical heart—we read in Newman — the spiritual heart is "hidden from view; it is carefully and securely guarded; it is not like the eye set in the forehead, commanding all, and seen of all: and so in like manner the sacred doctrine of the Atoning Sacrifice is not one to be talked of, but to be lived upon; not to be put forth irreverently, but to be adored secretly; not to be used as a necessary instrument in the conversion of the ungodly, or for the satisfaction of reasoners of this world, but to be unfolded to the docile and obedient; to young children, whom the world has not corrupted; to the sorrowful, who need comfort; to the sincere and earnest, who need a rule of life; to the innocent, who need warning; and to the established, who have earned the knowledge of it."10 Let us note that the purpose of all the components enumerated here is primarily to effect a certain practical result, and not to satisfy theoretical curiosity, i.e. to be lived upon, to convert, to bring comfort, to give a rule of life, to warn. And let us observe two important elements in this quote. The doctrine of the Cross (the Atoning Sacrifice) is "to be lived upon"-Edith Stein came to the same conclusion-and it is "to be unfolded to the docile

\footnotetext{
$8 \quad$ Ibid., 322, 323 .

9 E. Stein, The Science of the Cross, 116.

10 J. H. Newman, Parochial and Plain Sermons, 1233.
} 
and obedient." Indeed, here again we can see in practice the consistency of Newman's thinking, namely the importance of the intellectual and moral united in the person. Intellectual prowess is incapable of assenting to something that may otherwise be logically clear and distinct.

Here, the doctrine of the Cross or the science of the Cross is the Atoning Sacrifice. Hence, it is not the mere visible signs of suffering that matter, but their profound sense of Atonement. And here, again, is the true individuality emphasised, for it draws on its true form from the depth of (primeval) life. True individuality resides not in some spectacular feats of individual expressions, like images of an object reflected in numerous mirrors. The images are aspects of the object, but taken in their singular character they do not exhaust the whole of the object. We need to turn from the images and direct our eyes on to the object. Therefore, in our dealing with the world we should behave likewise, i.e. "begin with the world unseen. They alone enjoy [the visible world], who have first abstained from it. They alone can truly feast, who have first fasted; they alone are able to use the world, who have learned not to abuse it; they alone inherit it, who take it as a shadow of the world to come, and who for that world to come relinquish it."11

The true world, i.e. the world to come, is like the object hanging in front of the mirrors. Newman's figure resembles Plato's well-known vision of the people chained in a cave. They also need to turn their eyes from the images on the wall and direct them on to the object. In Plato, it is the true idea. In this world, we are doomed to live in the shadows. In the world to come they will flit away. Our task is not to be offended by what we learn as a world of shadows, but to be clearly aware that we learn only aspects. Moreover, the true knowledge resides in the invisible world.

The process of ascending, the actual climbing up the ladder, in the form of its physical metaphor is, indeed, like going away from oneself, or at least a solitary and individual journey. In fact, however, each step forward, if it is made in reality, authenticity, and conscientious honesty is like coming closer to the centre, i.e. to oneself and to God.

In his book on Newman, Stanley L. Jaki placed a question mark after the word "mystic." Newman's biographers shy away from calling him a mystic.

11 Ibid., 1235 . 
I think that, at least, some conditions are fulfilled. And there are other elements that smack of mysticism in Newman. Let me remind the reader of his simple assent as a readiness to respond to God's call. There is, in Newman, this tension between intuition and certitude. Intuition is most directly related to the purity of intention, and certitude is superimposed on reflection, and therefore may be prone to rationalization. Intuition is akin to the person's moral character. Indeed, Newman's ultimate goal seemed to be certitude, but even more than that it was important to attain this fresh and ever-new alertness to assent to the truth of values. In other words, to what God may demand of man. In one of his prayers we read: "Give me that true wisdom, which seeks your will by prayer and meditation, by direct intercourse with you, more than by reading and reasoning."12 Newman's hesitation between the serenity of certitude and the promptness of assent indeed results from the believer's feeling that assent is his manifest response to the call of a concrete situation. At the same time, when pondering on these two attitudes, we may conclude that there is no contradiction between them-they are like two sides of the same person.

It is the essential element of mysticism to seek this transparent, spiritual, and unmediated communing with a deity. Edith Stein observes in her comments on St John of the Cross that he "says little about the converse of human souls with each other [...], he is not interested in the notional means by which the communication is effected."13 Judging by what she has written, we find it only natural that in her phenomenological quests she met a kindred spirit in St John of the Cross and John Henry Newman. Let it suffice to remind the reader of the essential concepts of the Cardinal's theory of knowledge: natural reasoning, informal inference, implicit thinking, personal result-they all point to the spiritual dimension of the person. They all stress the solitary-indeed, mystic - path inside, not to become a recluse or misanthrope, but to be more personally present in the world and to be more responsive to God's calls. As we know, the "notional means" of communication Stein is writing about, for Newman belong to the weakest and, hence, least trusted because they are superficial and, consequently, the least personal.

If the soul is engaged only in this notional distance from the Creator, argues Stein, it is in danger of becoming distorted. This is something mystics stress, that the night is for human sense cognition, for the human senses. Verbal communication is subject to errors, "it exposes the soul to manifold deceptions and errors: it may regard a mere delusion or phantasm as the apparition of

\footnotetext{
12 J. H. Newman, A Newman Prayer Book, 15.

13 E. Stein, The Science of Cross, 116.
} 
a spirit [...]."14 The rationalists, as we know, proposed methodical doubt as a remedy against deception, the suspension of judgement. But we need to act when called to action. By keeping a distance from the object of our cognition, we place ourselves in danger of losing some important messages. Besides, this is not our natural condition.

I think that even in Newman's concept of conscience there is something mystical, especially when he stresses the danger of the interposition of reasoning between the voice of conscience and action.

\section{3}

\section{Selfhood— the Essence of Originality}

It suffices to be ourselves in order to be individual, i.e. to save our individuality; and this turn to the self in quest of selfhood has something of the quality of an intrinsic dialogue with God inside man. As individuals, we are not products of one mechanistic and replicable template, so we do not have to prove that we are unique. On the contrary, we easily fall into the trap of collective awareness and collective thinking once we decide to search for individuality outside. For it is then that we fall under the spell of stereotypes and limitations, or else pursue the unknown tracks laid down by others, as we seek to hold on to the experimentation with foreign lifestyles. There is one song that is especially fashionable at the moment, namely, the song of diversity. This kind of diversity, however, does not result from the discovery of individuality, but apparently from a frantic quest for difference. The more different I am from others, the better. But then it appears that this feverish quest for difference pushes us into the old rut of the stereotype. Newman follows Augustine in his belief that real individuality resides in inwardness, not in outward manifestations. He learned from Augustine a total reliance on God and the importance of introspection, which Gottlieb describes as looking "into his own mind to see the truths that God had left there for him."15 But Newman did not limit himself to pondering the contents of his mind, he also contemplated his own attitudes toward the revealed truths. Unlike Augustine, he was interested-after the Aristotelian fashion - in man in action. Like Augustine, however, Newman decided that it was time to stop doubting. His cause against doubting is anti-sceptical just like Augustine's was. Which house looks more unique: the one inhabited by its owner or the one abandoned by its owner? It is the owner present in his own

\footnotetext{
14 Ibid., 117 .

15 A. Gottlieb, The Dream of Reason, 395.
} 
house that renders it as something special and unique. Therefore, the person inside his selfhood is the person at home. And this is the essence of originality at the same time.

Newman's and Stein's decisions could only come from a mature personality, from their profound selfhoods, where no one makes others responsible for his own fortunes. Therefore, in a sense, they both died in similar circumstancesas solitary and fulfilled selves. Newman, surrounded by friends but, at the same time, safely enclosed in his personal certitude, in which his heart conversed with the Heart of the Lord; Stein, surrounded by her fellow believers and filled with her personal certitude that this must be the incomprehensible way chosen by the Lord for her. She did not know at the moment of her personal revelation, when she confessed "This is the truth," what might be the destination of this new journey she was gradually undertaking. And the external form of destination may be as different as different are two lives: Newman, reposed in his armchair, as we remember the last picture of him, and Stein holding tightly to the cross of suffering.

What are the thoughts of the heart in Stein's interpretation? They "signify the original life of the soul in the ground of its being, in a depth that is beyond the division into diverse powers and influences." It is the inmost part and the dwelling-place of God. Because this place is so hidden, it becomes mysterious even to the soul itself. This inmost sphere is "primeval life [...] without form."16 I think we may identify this form of life as Stein understood individual form. I understand thoughts of the heart as reflections of this form. They are true expressions of the person, but they are not notions. They have no forms, they are no creations of the thinking intellect, and they are beyond rational knowledge; indeed, they are implicit (Newman). Stein writes that our sensing of these thoughts of the heart "lacks the clarity of purely rational understanding; on the other hand, it is richer than this."17 In like manner, the heart rather is than speaks. Newman, for his part, places the doctrine of the Cross, which he calls "great and awful," in "the heart of religion." And he goes on to explain what he means by the heart by analogy with the biological organ quoted previously. We must bear in mind this analogy between the spiritual heart and the

16 E. Stein, The Science of the Cross, 118.
17 Ibid. 
physical heart, when analysing the language of the heart in the context of the Cross. Inasmuch as the physical heart supports our vital functions, the spiritual heart supports our personal life. And what supports our physical life is therefore not intellectual, hence it is not explicit, only implicit. It is in the heart that we realize what we are assenting to. We keep in the heart the treasure of our very person. The most important things are not on the surface, they are kept in the heart; therefore, the doctrine of the Cross is "not one to be talked of, but to be lived upon." This is incredibly interesting, as I think, that we have found common ground between the two thinkers. And this common ground is unlike a set of shared opinions, but common participation in something that is beyond theoretical views.

The thoughts of the (spiritual) heart are implicit, so they can hardly be translated into the explicit form. At the same time, we learn that they are "richer." I understand by this that they are much more imbued with what is personal, and what is truly personal is incommunicable. More imbued with the personal, because they are free from reflective intrusions. Hence, it is quite logical to claim that which is incommunicable is not explicit. And any efforts at making it explicit are doomed to failure. The real person is inside, i.e. in the heart. As we recall Newman's "unperceived impressions," we can now say that they arise in the heart.

\section{5}

\section{Interior Perception}

This is a very interesting point and very much in accordance with Newman's intuitions. As I have said, he elaborated much on natural reasoning, natural inference, and a kind of internal conversation. The soul is set aside from the mind and decisions of the will. Owing to our personal faculties, the primeval life that resides in the depth is brought to light; to be more precise, only its glimpses, it is apprehended by interior perception. Interior perception is different from the first sensing. Who can perceive these first motions? Stein answers thus: "Only a person living perfectly recollected in his inner being watches faithfully even those first movements." ${ }^{18}$ And here we are brought again to Newman's perception that only those who are whole can heal others. ${ }^{19}$ Let us add more elements that characterise such a person. He is one whose words are real, who lives in obedience to his own conscience. In other words,

\footnotetext{
18 E. Stein, The Science of the Cross, 119.

19 See J. H. Newman, Apologia, 147.
} 
one who lives in the unity of his being - the intellect and morality under one roof. Such a person is "perfectly recollected"-I am assenting to something and I know that it is I who is assenting to it.

The Carmelite Saint observes:

This brings us to the second reason why a man's inmost being is hidden from him. As has been said, here the soul is truly at home. But, strange though it may sound, it is normally not at home. There are but few souls that live in and from their inmost being; and even far fewer that are constantly living in and from it. Naturally, i.e. according to their fallen nature, men stay in the outer rooms of the castle of their soul. Whatever comes to them from outside draws them outward. ${ }^{20}$

In this beautiful quotation we again notice some (intentional or nonintentional) Newmanian tracks. Those who do not live in their depth are not at home, that is, they remain in chaos. They are torn between pleasure and pain, but because they do not live inside neither of these can bring them gratification-neither the satisfaction of pleasure, nor the evasion of pain. Indeed, they live at the Kierkegaardian aesthetic stage. And the main reason for this is that they treat pleasure and pain in isolation from everything else, primarily from their true selves, forgetful of the necessity to bring any dissipated elements into a whole, i.e. into a system. They go and return, as the occasion might be, without trying to find any sense of either direction. They remind us of homeless vagabonds, deprived of any set goal in their lives. Existentialists and writers provide plenty of examples of such types. A classic example is the hero from Camus's novel The Stranger. They remain temporarily satisfied with what is expedient and what brings them fleeting satisfaction. Indeed, if certitude is a journey towards a certain goal, it is not yet accomplished. There are few persons who live in their depth, who are so simple and undivided inside. More often than not, all the processes of rationalization are at work, which thwart the realization of the inmost being. I presume that the reader may feel somewhat confused now. If the inmost depth is unknown and implicit, how can we reach it at all, or, better still, how can we learn whether we have reached it, we have come closer to it or we have gone a long way from it?

The answer is surprisingly simple: we can learn about it only indirectly. We can pass judgement on it based on external manifestations. I have already mentioned some of them: reality, simplicity, conscientiousness, purity of motives, 
personal integrity - such are the clear signs of our residing in the centre of our inmost being. In general, going inside is a lifelong process, the process of growing.

The soul can move inside due to its being an ego. It is in its inmost sphere that the soul can truly be free, i.e. at the source of what primarily emanates from its depth without any interfering mediations. The interference may come from the inside (rationalization triggered by conceit, envy, greed) or from the outside (false authorities, temptations). In this "deepest point $[. .$.$] it can$ decide on its own being." The decisions that are made from a more distant point are superficial and inadequate, for "it is mere chance if a decision turns out to be adequate, for only in the most profound point are we capable of judging all things by their ultimate standards."21 The more distanced we are from our inmost beings, the less perfectly free we are, because, inasmuch as we are distanced, we are not wholly masters of ourselves, we are subject to external influences, we are, so to say, distracted. Man's destiny is "to live in his inmost being and to master himself in a way that is possible only from this inmost sphere." 22 Who am I when I am distanced from my centre? Who am I when I am coming ever closer to it? What are the criteria by which we can judge the distance from the centre? Such questions may naturally arise. We may attempt to answer them. If, in our inmost depth, we are most truly free, and we know that it is implicit, then it is beyond any conceptualisation. Therefore, inside we are, so to say, naked - without plans, schemes, memories, or anticipations. We are where we are, and what we really are. This state indeed reminds us of a mystic state. We find in St John of the Cross detailed descriptions of how the soul should purify itself of any concepts. And in philosophy we have the picture of Kierkegaard's two tombs. The aesthetic character is always somewhere else than where he should be-and this is the essence of his despair. He recalls things he should hope for, and he hopes for the things he should recall. Therefore, he is never in his true inmost depth.

It is only from this inmost sphere that the person can have a true relationship with the world because only there is he at one with his true self, is he truly himself, "and only from here will he be able to find the place in the world that is allotted to him."23 No wonder, then, that Newman, rather than trying to change the Anglican Church, set out on his journey in quest of his true ethos, of his genuine place. He realized that it was not the outside that must be transformed, that the true sanctuary is his own self.

\footnotetext{
21 E. Stein, The Science of the Cross, 120.

22 Ibid.

23 Ibid.
} 
Since the thoughts of the heart take the implicit form, they are hardly accessible to the self itself, unless vaguely, as only God knows them. Edith Stein stresses the fact that the question of the relationship of freedom to its inmost sphere does not come from St John of the Cross. It is suggested, therefore, that it is her own addition. ${ }^{24}$ We have to understand that, for mystics, but also for Stein and Newman, freedom does not mean in the first place the free expression of one's self, let alone totally free choice in the sense of free options (as is viewed in the negative aspect of liberty). In their case, freedom in its primary sense means a readiness to surrender the whole of one's being to God in obedience, i.e. to the duty that results from man's obedience; hence, the Cross is, for Newman, the measure of the world and for Stein the special science. Therefore, Stein concludes, "with regard to this highest stage of the personal life there is perfect agreement between the mystical doctrine of the two founders of the reformed Carmel [St Teresa of Avila and St John of the Cross] and the view that the inmost region of the soul is the sphere of the most perfect freedom."25 It is in this inmost region that I am truly myself, that I have myself at my disposal. Not in the sense that I understand everything, and can communicate it to others. It appears that the person is most free in the implicit sphere of his mind. First of all, because this sphere eludes conceptualization, and therefore it simultaneously eludes rationalization. We can even say that it is good for us that the implicit contents of our very being are beyond our reach. Therefore, they can become, firstly, the goal of our constant struggle, the ultimate point of reference; and, secondly, they are indestructible — one can kill and torture an individual, but one cannot touch the person. I know that this statement may sound somewhat paradoxical, as we have already said "know thyself." On second thoughts, however, it is not paradoxical at all. It is true that the implicit sphere eludes our conceptualization, but nor do we need to know it in this conceptual, explicit, form.

In view of the above, and of what I have said so far, I would like to put forward the following thesis: the heart is composed of what is invisible and unmeasurable, it is akin to the abyss of existence and primeval life. The heart is the sphere of true existence. If, as Newman claims, man can really assent to something he does not understand, therefore, in like manner something that is unnameable, or cannot be described, can exert a visible effect on man's

$\begin{array}{ll}24 & \text { See E. Stein, ibid., } 121 . \\ 25 & \text { Ibid., } 122 .\end{array}$ 
actions. In this sense, we may speak of the intransitive effects of our actions, i.e. their results remain in the agent. ${ }^{26}$ The person, throughout his lifetime, amasses not merely experiential data out of which he constructs theoretical knowledge. Equally important, or even more so, is his moral experience, his decisions concerning moral good or evil, that come to constitute the implicit abundance of his person. And, aside from theoretical knowledge that any person has, there remains this powerful, invisible, unnameable spiritual core that is brought to light by the person's simple and real assent to values. I think we can call this vital space the heart. Thus, the heart, as the unnameable sphere, indeed becomes Newman's personal result. Personal, because it surpasses whatever belongs to our general acquisition of information. The heart then resembles the freshness of the simple assent. And the heart is the personal pulsating and vibrating organ with which the person responds to values. In like manner, Newman's and Stein's spiritual paths cross together. The more we respond to values, the more sensitive the heart becomes, for the fabric of the heart is composed of our decisions and acts, of the good we have assented to and realized. In other words, it is composed of facts, not of mere plans or dreams. Its power does not reside in anything sentimental. It becomes powerful, although its power does not consist in arguments. Consequently, in his confrontation with reality the person is empowered not only with a capacity to methodically analyse problematic issues, formulate theorems and solve tasks, but is additionally empowered by the spiritual dimension that is powerful, yet indescribable; it does not even seek its manifestation in arguments.

Indeed, there is something mysterious in this logic of the heart. It is the logic of the person who has realized the truth. It is not composed of knowledge which can be given an explicit form, and yet it is a knowledge! In this sense, the science of the Cross can also be the science of the heart. And the personal result is the result of the heart! The power of the heart comes from reality, i.e. from the personal realization of reality. Therefore, it is indeed a personal result, not a general statement on some universal truths.

The saint Carmelite author asks about other people if they are capable of this mystical marriage, i.e. a close relationship with God without any demonstrative knowledge. We can reformulate this question in the context of Newman and say: are all people capable of personal certitude? Are they capable of real assent? And to either question our answer must be in the positive. If each soul has this inmost sphere, and it is only natural that each soul should have it, for it

26 Cf. Karol Wojtyła's discussion on the transitive and intransitive effects of human acts (K. Wojtyła, The Acting Person, trans. A. Potocki, Dordrecht: R. Reidel Publishing Company, 1979, $149 \mathrm{ff}$. 
is their ontic endowment, then the only problem is where the soul has decided to cover the distance (in each case individual) from its inmost sphere.

And here Edith Stein mentions the sensual man who is further from this sphere, for he is occupied with sensual enjoyment. I have already given the example of Kierkegaard's aesthetic man, the epitome of whom for the Danish philosopher was Don Juan. Then we have the seeker of the truth. Much depends on what kind of truth this person is seeking: the truth of science, or only a mere amassing of "particular kinds of knowledge." If such a man seeks the Truth of his life, say, wisdom in its most fundamental manner, he is closer to the inmost sphere. Looking at the matter in question from the Newmanian point of view, we would say that the person who gives his real assent to the truth, who realizes it - all of these terms belong to his vocabulary-is closer to his inmost sphere than he who considers these matters only in a theoretical manner, the mere subject of learned deliberation. I have tried to explain this point above, i.e. to show the indirect way we learn our whereabouts in relation to the inmost sphere.

Newman, however, does anticipate that there is a passage to the inmost depth inasmuch as there is a passage from notional to real assent. And because such a passage exists (always individual as to its space and time), man is not bound to his place; in like manner, there is a chance for transition and, consequently, growth. At times, it is like a sudden awakening: where am I? Is this my place? Any event may occasion such alertness. A casual conversation about death, for instance, can be confronted with the sudden realization of its reality, like the example of Randy Pausch I gave in Chapter 2. Or a mere theoretical discussion about suffering can suddenly turn into a willingness to help someone close who suffers, even in the case of the sensual man, "for no type is tied exclusively to one sphere, only one will always be more powerful than the other." ${ }^{27}$ In the case of the sensual man, however, such a prompt decision to act may take much more effort. Depending on our, say, primary character, we may find it more or less difficult to approach the inmost sphere. When man is naturally attached to a self-indulgent lifestyle, he will only reluctantly consent to discipline and rigour. In other words, the path inside can suddenly open up to us. The Cross is a great symbol of the domination of reality over theory, and it is, indeed, the measure of the world as it brings a totally external point of view. The Atoning Sacrifice that it denotes introduces an entirely new logic-a higher logic, Newman would say—a totally disinterested offer for those who do not deserve it. 
We could even say that human beings are systems composed of aspects, but we cannot reduce them to these aspects, nor abstract from them towards some general terms. In both cases there is always a danger of depersonalization. ${ }^{28}$ We must also constantly bear in mind that if all the contents of the human mind were explicit, then the precondition of reconciliation between different minds would be a discussion (between the one who knows and the one who does not know). It would suffice to add more arguments to those available; in this manner, a mere accumulation of arguments would be sufficient to bring someone round to our point of view. But the mind is a reservoir of an indefinite number of unknown elements that should be subject to the higher logic of the Cross. Its microworld ultimately requires conversion, not merely discussion. In other words, certain components of personal life must be discarded, some ethos must be abandoned. Furthermore, it is not the immanent logic of the intellect, active in the creation of ever new forms and styles, that can pave a safe path, but the unrelenting and permanent principles of the Cross. The Cross is a substantial testimony that calls for a respective response, if not equal in its form, then at least equal to its meaningful contents.

Man immersed in pleasure may find it especially difficult to go outside of himself in order to abandon his lifestyle. And here, again, we find an aspect of Newman's analysis in which, we remember, he stressed the importance of intellectual and moral character. We need the integral development of both in order to overcome the original state of chaos, the contingent fortune of each man. Theoretically, i.e. notionally, the sensual man may understand what is being said, but he fails to see the reality behind the words and act accordingly. In the case of a suffering person, when his assistance is in demand he may simply fail to notice the person. Edith Stein puts this discrepancy between theory and practice superbly when she notes: "The words are heard, perhaps their immediate meaning is still understood, but the deeper region where their true sense would be grasped is in ruins." ${ }^{29}$ Indeed, Newman was also well aware of this intrinsic incompatibility between words and deeds. Comprehension does not entail action. We are talking here about a fragmented man, a man who is so enslaved to one single sphere of his, e.g. the sphere of pleasure, that he cannot muster himself to action, although, theoretically, he has a perfect command of what should be done. Newman would say that he is not at one with himself.

In his analysis of the heart vis-à-vis reason, inspired by the traumatic events during the war, the Austrian psychologist Bruno Bettelheim (1903-199o) put it

28 J. Crosby, The Selfhood of the Human Person, Washington D.C.: The Catholic University of America Press, 1996, $10 \mathrm{ff}$. 
beautifully in his book where we read that "heart and reason can no longer be kept in their separate places. Work and art, family and society, can no longer develop in isolation from each other. The daring heart must invade reason with its own living warmth, even if the symmetry of reason must give way to admit love and the pulsation of life.

No longer can we be satisfied with a life where the heart has its reasons, which reason cannot know. Our hearts must know the world of reason, and reason must be guided by an informed heart."30

Bettelheim wrote these words in his 196o book, fifteen years after the hecatomb of World War Two, the German concentration camps, the Holocaust, and the Soviet camps. The war can be explained (if it can be explained at all) in philosophical terms by referring to the atrophy of the intellect, an intellect that came to the conclusion that some races are superior to other races. The superior races are masters with the only right to live, to reproduce, and to develop. The appropriate place for the subordinate races, thus arbitrarily determined, is to serve the master race. Torture and gas chambers are only consequences of such presuppositions. Stein had long predicted the suffering of her Jewish nation. She was an intellectual, she found no difficulty in bringing such thinking into its consequences. Whenever the human being decides to remain disintegrated and decomposed, with atrophy and dystrophy as incompatible elements of his very being, he must face the negative consequences. And Bettelheim knew very well what he was writing about, as he was a prisoner of the concentration camps of Dachau and Buchenwald. We can only imagine what kind of book Edith Stein would have written if she had survived Auschwitz. I have no doubt that she would have followed similar lines: the heart informs reason, and reason teaches the heart. We find the same elements in the encyclical letter Caritas in Veritate (Benedict XVI). The human being must develop in the harmonious unity between heart (love) and reason (truth), otherwise he is in danger of becoming a beast.

The American Bishop Fulton J. Sheen put it excellently when he wrote: "Finally, totalitarianism came on the scene to say that, since man is intrinsically corrupt, he cannot be justified by faith, or by works, or by the Sovereign Will of God, but only by the collectivity which absorbs man; this, we are told, will do away with human depravity by substituting state conscience for individual conscience and a dictator for God."31 Immersing the human being in the Pan-rationalistic reality (the State, History) in a Hegelian manner

\footnotetext{
30 B. Bettelheim, The Informed Heart. Autonomy in a Mass Age, New York: Avon Books, 1960, VIII. 
is no remedy against the individual vices which cause social unrest. We need to address the human being in his integral unity. Dealing with individual parts separately serves only further decomposition and brings no repose in return. Sheen rightly observes: "To uncover the motives of sin, by studying the patient's past, is no cure: sin is not in the understanding alone, nor in the instincts; sin is in the will. Hence it cannot be broken up as another complex may be broken up by dragging it into the consciousness." ${ }^{32}$ Naturally, we sense here a very strong anti-Freudian element. At the same time, let us note that this integral view of the human being fits the similar attempts we find in medicine very well. It has long been affirmed that the patient should not be resolved into his constituent parts. If he suffers from indigestion, it does not follow that he himself has become the stomach or the liver (as can be often heard in medical jargon).

True Personality Comes from the Depths

For Edith Stein, not only is the inmost depth the seat of our true self, butabove all- "an ultimately adequate decision is possible only in the very depths of the personality." And then she continues by saying that man is not "master of himself," if "he has not yet realized the depths of his own interior being." ${ }^{3}$ Words float on the surface and verbal communication is often superficial. And "realization" has its important place in Newman's vocabulary. Indeed, in the case of notional assents we rarely realize what we are assenting to. Frequently, we become excited and enthusiastic about opinions we support one day and abandon another, or we casually imitate others, thinking that we are manifesting our own views. Therefore, realization must come about no sooner than I realize who I really am, i.e. whether it is really I who formulates concrete beliefs. An act is genuinely personal when the person is genuinely, i.e. not only physically, present in it—when the person realises what he is doing.

Like Søren Kierkegaard, to whom I have frequently referred in this text, Stein observes that the sensual man can move to the ethical stage. In such a case, especially if this primary stage is permanently fixed and has turned into a habit, man may need an extraordinary awakening: "no man is naturally capable of surveying all reasons for and against which influence his decisions." ${ }^{34}$ The sense of this quote can be interpreted as the difference between inference

\footnotetext{
32 Ibid., 74.

33 E. Stein, The Science of the Cross, 124.

34 Ibid.
} 
and assent-that well-known issue Newman discussed. In his analyses, he came to the same conclusion, namely, that man's natural assent is not the result of formal inference in which the human mind undertakes this tedious process of a meticulous inspection of all premises; John Henry writes, as previously quoted, about one act with which we give assent to a given truth, an act which resembles "an unwritten summing-up [...] of an algebraical series." Stein is, therefore, alluding to Newman's distinction between inference and assent. Henceforth the leap from the aesthetic stage to the ethical stage is like the leap from notional assent to real assent. We are struck by an image rather than go through a long series of inferential calculus. Instead weighing all the pros and cons we make a decision and action follows. Such is our natural conduct in concrete matters. This is our informal inference and natural (personal) reasoning. Only God knows all reasons, all these interior vacillations as the pros are weighed against the cons. Man can only live "in this certainty of faith," so he can repose in this faith and "must strive to recognize what is right in God's eyes." This conclusion "implies that only the religious attitude is truly ethical." ${ }^{35}$ Because the matter is too complicated, therefore it is safer to hold on to religious tenets which provide guiding rules.

And here we have arrived at the Augustinian moment, for the natural seeking and longing is the divine will. The consciousness of doing right is not coequal with actually doing right, but the decision to do right is the precondition of justification. In other words, my knowledge about what is right is never perfect, and to attempt to attain perfection is doomed to failure. We do not have to resume a detailed analysis in order to act, neither is it necessary. Thus our procedures in daily acting — we already know it from Newman - is that of belief; the attitude of belief is our natural mode of acting. Stein continues: "If a man seeks what is right only here and now and decides according to his lights he is by this very fact on this way to God and to himself, even though he may not know it." ${ }^{36}$ As we remember, this is what Newman described as using oneself; we have to use ourselves as we have no one else to use. (Let us note in passing that the quotations here resemble Adam Smith's invisible hand, although for the Scottish philosopher it was the mechanism to be employed in the economic sphere. The logic, however, is the same: be satisfied with the modest I-perspective and do right what you have recognised by your reason and with the approval of your conscience- the impartial spectator. Man does

35 Ibid.

36 Ibid. 
not know the mind of God. He may, however, believe to have approached it in his righteousness.)

Naturally, we are not left alone in this journey inside. Only the man united with God can become master of himself. Edith Stein follows the same paths Newman has defined in his sermon: reason, principle, and conscience. Since we cannot elaborate an overall scheme that would satisfy all, we have to rely on the individual person and his potential ability to do right, for he is endowed to act respectively. The saint Carmelite explains: "If a man seeks to do the right thing on principle, i.e. if he wills to do it always and everywhere, he has decided about himself and placed his will within the divine will, even if it should not yet be clear to him that right is identical with what God wills. But if he is not clear about this, he has not yet found the safe way to what is right; and he has disposed of himself as if he were already master of himself, though he has not yet realized the depths of his own interior being. The ultimate decision is possible only before God." ${ }^{37}$ We find in this quote the basic Newmanian tenets like acting on principle and realization. Only the person who lives truly in himself, i.e. who knows what he is doing and wills to do it and experiences certitude about doing it, is acting in his own person. And another crucial point is that such a person may rightly believe that he is fulfilling his personal task entrusted to him by God. Ultimately, that he is doing what God wants him to do.

The man whose will is surrendered to God strives for what is right in God's eyes. And for the person who is thus united with God "this question is solved once and for all." ${ }^{38}$ We could paraphrase Newman's words here: he knows what he knows. He realizes the truth.

Man can dispose of his innermost being and he is also called to preserve it. Man can be internally divided, so he can be internally far from his depths. He is not, then, master of himself. The function of understanding does not come from the depths of one's interior, says Stein, and this is a very profound remark, for the function of understanding is akin to what we all commonly grasp when using the logical apparatus. But it is "those depths" that "do awaken in affective and dispositional life. Then your soul opens itself with that which is proper to it when it's at home with itself." ${ }^{39}$ I think we can easily find the kin traces with Newman's image which can be a connatural reflection in the mind. But the soul must be "at home with itself," in Newman's parlance the person must be whole, united, and integrated. It must be noted that not all affections issue

\footnotetext{
37 Ibid.

38 Ibid.

39 E. Stein, Philosophy of Psychology and the Humanities, trans. M. C. Baseheart, M. Sawicki, Washington D.C.: ICs Publications, 2000, 228.
} 
from the core of the person, i.e. from the soul, not all of them are "core-valent." There are values which pertain to the unity of our psyche, but our "soul is not implicated in [this experiencing]."40 They are, so to say, "soul-less."

Let us note that the description so far boils down to introspection. In order to retain individuality one must go inside rather than be dispersed in external forms, some of which are weird. Expressivism is not a remedy to rescue individuality, a fact that has already been stressed in this book. The conclusions we have arrived at sound indeed logical: the inside must be genuinely most individual and original because it is perfectly inaccessible to anyone beyond the self. We do not need to struggle and prove the external world how original we are, for the most original is one who remains inside. Newman enumerates the main elements of this kind of wisdom: "innocence, simplicity, implicit obedience to God, tranquillity of mind, contentment [...] because God works for those who do not work for themselves [...]."41 Individuality and, consequently, originality consist not in pouring oneself out, but in remaining inside. All this comes down to being wary of ostentation.

The fear of ostentation, or in other words the form that triumphs over the contents, thus making man unreal, is constantly on Newman's mind. This danger echoes in romantic poetry as a warning against inauthenticity. Man should witness to God "without pretension, or affectation, or rude and indecent ostentation." ${ }^{42}$ After all it matters little how people censure the believer, but what counts is "whether in God's judgement he deserves the censure [...]."43 Newman was always ready to subdue to the authority of the Church, even when he was member of the Anglican Church in which the individual attitude was more prominent; when he found the ethos of his Church false, he decided to quit. His main purpose, however, was not to undermine authority, but rather to enforce it. The more so when he joined the Roman Catholic Church. Therefore he bids his fellow believers "to shelter our personal profession under the authority of the general body." 44 What we need is secrecy and humility because-philosophically speaking, as Newman is always trying to proof-such is the nature of our knowledge, much of which is implicit and tacit. Rather than professing the truth as self-proclaimed prophets we shall do much better if we remain within the bosom of, and obey, the Church. Newman

\footnotetext{
$40 \quad$ Ibid., 229 .

41 J. H. Newman, Sermons Bearing on Subjects of the Day, London: Longmans, Green, and Co., 1891, 299 .

42 J. H. Newman, Parochial and Plain Sermons, 98.

43 Ibid.

44 Ibid., 99.
} 
bets that our profession should rather be a spontaneous process, words flowing from us without premeditation, and deeds following words; ultimately, deeds suffice. Newman shunned ostentation. Let us observe how coherent his thinking is. He is always on his guard when individual speculation intrudes in doctrinal matters; when speculation seeks to get the upper hand. This mediation of the imperfect intellect is in constant danger of making mistakes.

Let us note in passing that some people say today that clergymen should stay out of politics, a very popular claim at the moment. What does Newman have to say? Obviously, they should not covet high places or be ambitious, but to demand that they "should not express an opinion and exert an influence one way rather than another, it is plainly unscriptural."45 Here again he stresses the importance of being judgmental, an attitude which in Stein would mean being responsive to values. And like in the case of being non-ostentatious but moderate, gentle, and humble, avoiding contentious words, we should nevertheless pass judgments on the reality around us. It is good or bad, not neutral in any sense.

Primeval Life Accessible Yet Not Comprehensible

Following Edith Stein, the most original in us is the primeval life, not the external forms that we choose for the sake of self-expression. Now the problem is that we have no direct access to this inmost centre of our selves, we cannot examine it, let alone perceive it with our senses or render it in an intersubjective and communicable form, yet nevertheless it remains the ever-present source of individual emanation. We should draw on the inside for what is outside. It is in contact with the primeval and non-conceptualised life where the human being is free with the utmost freedom that we can attain what is truly personal and truly individual. This point is in agreement with what I have said before. The inside is composed also of the non-conceptualized (resp. implicit) sphere and yet it beams with life, but we do not have to (nor can) put it in explicit forms. Indeed it is enough, as we said, if our intentions are pure, then we come close to what is expected of us, i.e. what is in accord with the inside. This is logical, while belief is unlike theoretical knowledge that can be demonstrated.

Therefore primeval life is not deterministic, hence when its impact is released and transformed into many internal forms and external expressions, one can become an Anglican or a Roman Catholic, for-as I have already 
said-in all religions one finds some common elements. The point is, however, that one should strive after what is truly his, what he can realize, and he cannot do it unless in his inmost self. Edith Stein notes, as I have already quoted it before, that "man is destined to live in his inmost being and to master himself in a way that is possible only from this inmost sphere." This fundamental choice is carried out amidst various circumstances, what we generally call ethos, other people's choices, and the historical background. Going inside resembles the Husserlian "zurick zu den Sachen [back to the things]," and John Paul II's poetic vision portrayed it as going to the source of the stream.

Since primeval life is not given to us for analysis, we can only describe certain attitudes as demonstrative of our proximity or distance from it. Newman focuses on "simplicity in act, purity in motive, honesty in aim," ${ }^{46}$ they altogether make up the essence of innocence and frankness. In other words there are modes of behaviour that bring us closer to the self. Such is the way of life that the believer should follow. John Paul II in his meditation Roman Triptych notes the memorable words:

If you want to find the source, you have to go up, against the current, tear through, seek, don't give up, you know it must be somewhat here. ${ }^{47}$

Primeval life is like an unquenchable fire that radiates with personal truth and authenticity; we need to remember that "personal" does not mean here someone's "personal secrets". No, rather it denotes the ontic sphere, something that belongs to my very being, not something that belongs to the conscious part of my being. Then it depends on the individual person, on his simplicity, purity of motives, and honesty whether the truth and authenticity will manage to be conveyed outside in individual acts. Or whether they die down in artful and artificial behaviour. And it matters little if some believers are accused of being artful and artificial, but it does matter what they really are. Let us invoke the metaphor of transparency again, the clean mirror that portrays perfectly the reflections of objects on its surface. Inasmuch as the person grows in the truth of his very being, so he is ready to give real (spontaneous) assent to real values.

There is a difference between outward obedience, and interior assent. This issue is important not only from the point of view of its historical

46 J. H. Newman, Sermons Bearing on Subjects of the Day, 299.

47 John Paul II, The Roman Triptych, archive.org/details/poetryofjohnpaulıoojohn [accessed on 10 August 2019]. 
considerations, when concrete examples of persecutions are examined. The persecution of people on account of their religious beliefs is not a thing of the past. When Christians comply, for the reasons of meekness and humbleness, to the authorities they should renounce, they fall under the severe judgement of being inoffensive. ${ }^{48}$ But, Newman argues, they only "yield outwardly; to assent inwardly would be to betray the faith; yet they are called deceitful and double-dealing, because they do as much as they can, and not more than they may."49 Hence the science of the Cross and the language of the heart are rendered as the mystery of the person, especially the believer who can hardly be understood unless we learn the Christian system. The individual person has his unique imprint on whatever he is doing, the more so the person as believer is united in his inmost centre.

We are dealing with the complex unity of the person on the one hand, and the pluralism of sciences designed to study the person on the other. These sciences have divided the person into various aspects which they thereafter attempt to examine. In order, however, to render an adequate picture of the whole person one must not forget that we are studying the person as one system, with the various aspects thereof being merely minute elements of the overall system.

Christians resume silence when persecuted, for the doctrine of the Cross imparts its specific logic on this renunciation of the world. And Newman's words testify to his mystic attitude when he says: "Do nothing, and you have done everything." ${ }^{50}$ Such words naturally agree with Stein's analysis of St John of the Cross's writings, for "the truth has in itself the gift of spreading, without instruments; it makes its way in the world, under God's blessing, by its own persuasiveness and excellence [...]. ${ }^{51}$ It is intriguing that to the degree to which we approach our innermost sanctuary, we become open to the "higher logic" of which Newman wrote. Going inside means - if I may call it that way-more apprehension but less communication.

The Carmelite mystic to whom Edith Stein devoted some much time and effort ran the similar paths of thought. We read in St John of the Cross that "faith and love are the two guides for the blind; they will lead you, by a way you know not, to the secret chamber of God. Faith, the secret of which I am speaking, is the foot that journeys onwards to God, and love is the guide that

48 This criticism is in some places of the world translated into liberation theology that seeks to marry the rosary with the gun.

49 J. H. Newman, Sermons Bearing on Subjects of the Day, 302.

50 Ibid., 303 .

$51 \quad$ Ibid. 
directs its steps." ${ }^{22}$ Lack of self-knowledge creates nominal Christianity; selfknowledge is the precept to the word of Scripture.

Jean Guitton wrote in this same vein in his text Le clair et l'obscur [The Clear and the Obscure] where we read: "If everything could be clear and if it were possible to make every essence transparent, we would not have research or obscurity. And conversely, if we were thrown into the incomprehensible, no action would be possible: we would resemble exegetes placed in front of a message written down in an unknown language. The chaos of clear ideas, the chaos of opaque existences are not made for us. And, to the truth, neither the clear nor the obscure has ever existed. Our climate is the mélange of the light and the shadow. In this temperate light, in this clear shadow we need to accommodate ourselves." 53 We live in chiaroscuro. The British writer of the twentieth century, Graham Greene, placed all his heroes against the backdrop of chiaroscuro, like Caravaggio's figures. This is perhaps the main reason why Greene loved reading Newman, for the latter had no fear of a mystery. We are doomed to live in between, hence neither absolute reason nor total ignorance is the right diagnosis of the human condition. Faith and reason go hand in hand.

Now it seems only natural that Stein should have suggested reading Newman to her colleague Roman Ingarden. Indeed implicit thinking — actually, not only implicit thinking but also implicit faith-is beyond ratio, as it is personal yet beyond conceptualisation. The steps of our personal reasoning were meticulously elaborated in the Grammar of Assent. We need the power of the person to adequately cope with given circumstances. Ultimately, however, the person must resort to God as the One who hides His will behind the visible curtain of phenomena. Enlightened speculation is of no avail to shed light on what is thus hidden, nor does man need to comprehend it. It is God who designs, and the human being can somewhat approach Him by going inside because God is not in the external manifestation of events. If God is the ultimate agent, obedience of the believer becomes the most important virtue. When this recognition - that God is acting - comes from the heart of the believers, as it should, "it approves itself to their reason, and they are able to recognize the expedience of obedience." 54 And, as Newman stressed in his critique of the enlightened view with its emphasis on the intellect: "The heart is commonly reached, not through the reason, but through the imagination, by means of

$5^{2}$ St John of the Cross, A Spiritual Canticle of the Soul and the Bridegroom Christ, trans. by D. Lewis, Grand Rapids: Christian Classics Ethereal Library, 2000, 22 (http://www.ccel .org/ccel/john_cross/canticle.html).

53 J. Guitton, Le clair and l'obscur, Aubier-Montaigne: Éditions Aubier-Montaigne, 1964, 11.

54 J. H. Newman, Sermons Bearing on Subjects of the Day, 305. 
direct impressions, by the testimony of facts and events, by history, by description. Persons influence us, voices melt us, looks subdue us, deeds inflame us. $\$ 55$ Let us note how important such considerations are when we, for instance, discuss the peculiarity of the relationship between the State and the Church. Christians have always seemed maladjusted to the world. Therefore if one wants to understand their behaviour, one needs to understand the Christian system in which the person is living in the world as a stranger. Newman makes some clever remarks. When bishops wish to avoid a popular movement, they subdue to the civil authorities and become "hypocritical again, if they did their best to repress it." ${ }^{n 6}$

55 J. H. Newman, Discussions and Arguments, 293.

56 J. H. Newman, Sermons Bearing on Subjects of the Day, 306. 